\title{
Estimating the Regional Economic Impacts of First Nation Spending in Saskatchewan, Canada *
}

\author{
Omid Mirzaei, David C. Natcher, and Eric T. Micheels \\ Department of Agricultural and Resource Economics, University of Saskatchewan, Canada
}

\begin{abstract}
It has been suggested that provincial and national multipliers may provide incorrect estimates of the economic impacts when examining distinct communities. Using data collected from a comprehensive survey of household spending on two First Nations in Saskatchewan, Canada, we use Input-Output models to refine regional multipliers for these distinct populations. We also estimate the rate of economic leakage and the economic impacts of First Nation spending. Results indicate that economic leakage rates for First Nation economies is roughly 90 percent; meaning that 90 cents of every dollar spent by First Nations for goods and services occurs off-reserve. Using our new multipliers, we find that First Nation spending contributes over \$741 million to Saskatchewan's GDP, creates approximately 11,244 full-time jobs, and leads to an estimated increase of over $\$ 462$ million in labor force income for the province. If policy makers intend to build on-reserve economies, strategies must be found to recapture off-reserve spending by providing comparable on-reserve goods and services. In the absence of on-reserve economic development, First Nation economic growth will likely remain stagnant with few wealth generating opportunities and lower standards of living for First Nation members.
\end{abstract}

Keywords: regional economics; Indigenous economic development; economic leakage; multiplier effect; InputOutput models

JEL Codes: R12, J15, R20, C67, R15

\section{INTRODUCTION}

Compared to non-Aboriginal Canadians, Aboriginal people in Canada experience lower quality of life measures across a variety of metrics. These include lower standards of living, higher

\footnotetext{
*This research was supported by the Toronto-Dominion Bank (TD Bank) of Canada. We gratefully acknowledge the important contributions of Alfred Gamble from the Beardy's Okemasis First Nation and Brett Baldhead from the One Arrow First Nation for their cooperation in this project. We are also thankful for helpful comments of Surendra Kulshreshtha and Eric Howe on this project. We sincerely hope the results of this research will advance the economic goals of First Nations in Saskatchewan.

Omid Mirzaei is a $\mathrm{PhD}$ candidate at the University of Saskatchewan in Saskatchewan, SK Canada. David Natcher is a Professor of Agricultural Economics at the University of Saskatchewan, SK Canada. Eric Micheels is an Associate Professor of Agricultural Economics at the University of Saskatchewan, SK Canada. Corresponding Author: Omid Mirzaei, E-mail: omid.mirzaei@usask.ca.
} 
poverty and unemployment rates, higher dependency on welfare, inadequate housing, lower educational achievement, higher rates of chronic disease, and lower life expectancy (Miller, 2012; National Collaborating Centre for Aboriginal Health, 2013; O'Sullivan and McHardy, 2008; Regan and Anderson, 2016). Researchers estimate that these conditions cost the Canadian Government $\$ 12$ billion annually (Canadian Centre for Policy Alternatives, 2013). While the complexities of these challenges defy a quick resolution, scholars and First Nation leaders have proposed various development strategies to overcome these conditions. For example, Stevens (2001) and Peredo et al. (2004) have called for greater entrepreneurial development and business investment to improve the economic circumstances among First Nation communities. Smith (2000) suggests that First Nations must regain control over their natural resources and use economic development as a vehicle to sustain their cultural identity. Chief Clarence Louie of the Osoyoos Indian Band (British Columbia) has similarly noted that "the remedy to most of our [First Nation] problems is economic development" (McDonald, Jake, 2017). The Assembly of First Nations National Chief Perry Bellegarde has stated: "Creating the conditions for First Nations peoples to succeed...is the best economic stimulus plan for Canada. It will add billions to the economy and save billions more in social costs" (Assembly of First Nations, 2016). For scholars and First Nation leaders alike, having a sustainable, self-reliant economy is considered to be among the most important factors for improving the socio-economic circumstances of First Nation communities in Canada.

Despite general agreement that economic development is the remedy for many of the challenges confronting First Nation communities, the development of First Nation economies has been difficult to achieve due to high transaction costs and policy constraints that have limited opportunities for First Nations to develop on-reserve businesses. With limited services available on-reserve, First Nation members must go off-reserve to acquire goods and services. The revenue that leaves First Nation reserves is then captured by regional businesses and urban centers, whose owners employ workers, pay wages, and expand businesses opportunities - revenues and benefits that are lost to First Nations. This situation has been characterized as 'economic leakage' where revenues leave First Nation communities sooner than optimal (Miller, 2012).

Unfortunately, the leakage that occurs on many First Nation reserves is nearly immediate and often significant. For example, Aboriginal Investment Services (2010) determined that 62.2 percent of all spending by the Six Nations (Haudenosaunee) in Ontario occurs off-reserve. This equates to a leakage of $\$ 160$ million annually that is absorbed by off-reserve businesses. The revenue that is spent off-reserve then has multiplier effects on the regional economy. These include the direct effects that occur when a First Nation member spends money on goods and services that are provided by off-reserve purveyors, the indirect effects when those service providers spends part of that revenue on new inventory and/or pay utilities, and the induced effects when increased labor income, originated from the direct and indirect effects, is spent within the economy (Miller and Blair, 1985; Carr et al., 2013). In the case of the Six Nations, the multiplier effect of $\$ 160$ million of off-reserve spending actually contributes \$208 million to the regional economy (Aboriginal Investment Services, 2010).

In collaboration with the One Arrow First Nation (OAFN) and Beardy's Okemasis First Nation (BOFN), we conducted an economic leakage analysis that quantified the total amount of revenue that left the OAFN and BOFN reserves, the types of goods and services acquired,

(C)Southern Regional Science Association 2020. 
and the locations of those transactions. Given the significant, yet often-unrecognized impact of First Nation spending, we then set out to determine the multiplier effects of all final demand from all $(\mathrm{N}=70)$ First Nations in Saskatchewan in order to determine the economic impact of First Nations' spending on the provincial economy.

The use of national and provincial multipliers originated from Input-Output models is a common approach in economic impact studies. Often researchers and policy makers use national and provincial multipliers because more local multipliers do not exist. However, this may exacerbate the problem leading to incorrect estimates. When dealing with regions that are distinct due to economic or demographic characteristics, creating new multipliers may be worth the added cost of obtaining this data (Deller et al., 1993). Using our survey data, we refine the provincial multipliers to calculate economic impacts of First Nations households based on their spending patterns. This contribution helps to create more accurate estimations of economic impacts in distinct populations such as First Nation communities.

These newly-calculated multipliers are used to estimate the total economic impact for First Nations' households of all First Nations in Saskatchewan, as measured by changes in provincial GDP, employment, and employment revenue. Furthermore, the total economic impact for First Nation Governments' spending is estimated. Developing pattern-based multipliers for First Nations' households, this research represents the first full accounting for First Nation spending on a provincial economy in Canada. This study could be of interest to people investigating the economic impacts of spending of distinct populations or regions. The use of refined multipliers reflects unique characteristics of First Nations households spending, which could lead to better estimations of economic impacts (Deller et al., 1993). This study could also be of interest to policy makers as it gives a relatively thorough estimate of total demand originated from economic activities of First Nation communities at a provincial level.

\section{RESEARCH SITE AND METHODOLOGY}

\subsection{Research Site}

As early as the mid-1600s, First Nations in Canada entered into a number of peace and friendship treaties with European nations (the 1664 Treaty of Albany was the first). These early treaties did not involve land conveyance, but rather set conditions for mutually beneficial terms of trade and to fortify military alliances (Natcher et al., 2009). However, after receiving semi-independent nation status from the British government in 1867 (British North American Act), Canada began to expand its territorial base westward. In an effort to facilitate the safe expansion of colonial settlement, the Canadian government launched a campaign of treaty making with First Nations. In exchange for relinquishing claim to vast tracts of their traditional territories, First Nations, who at the time were being ravaged by disease and starvation (Daschuk, 2013), were provided reserve lands that would be set aside from European encroachment. The specific formula for determining the size of reserves varied. For example, in Treaties One and Two, 65 hectares were added for every family of five or more. However, in Treaties Three through Eleven, families of five were awarded 260 hectares of reserve land. Through the treaty making process, 2,366 reserves were established across Canada, encompassing a collective land base of 3,377,826 hectares (Indigenous and Northern

(C)Southern Regional Science Association 2020. 
Table 1: Saskatchewan First Nation Demographics (Census 2016; Populations as of 2019)

\begin{tabular}{|c|c|c|c|c|c|c|}
\hline Saskatchewan & $\begin{array}{l}\text { On-reserve } \\
\text { Population } \\
\text { (total Pop.) }\end{array}$ & $\begin{array}{l}\text { Median } \\
\text { Age }\end{array}$ & $\begin{array}{c}\text { Secondary, } \\
\text { Post-Secondary, } \\
\text { Trades Certificate } \\
\text { (as \% of population with } \\
15+\text { years of age) } \\
\end{array}$ & $\begin{array}{l}\text { Average } \\
\text { Earnings }\end{array}$ & $\begin{array}{l}\% \\
\text { of income } \\
\text { from } \\
\text { Government } \\
\text { Transfers } \\
\end{array}$ & $\begin{array}{l}\text { Employment } \\
\text { Rate }\end{array}$ \\
\hline SK Non-Aboriginal & NA & 37.4 & 79.30 & & 11 & 63.50 \\
\hline Beardys and Okamasis First Nation & $\begin{array}{c}1,336 \\
(3,503)\end{array}$ & 24.3 & 58 & $\$ 24,987$ & 32 & 28.70 \\
\hline One Arrow First Nation & $\begin{array}{c}761 \\
(1,986)\end{array}$ & 20.5 & $39.50 \%$ & $\$ 21,651$ & $44 \%$ & $25.60 \%$ \\
\hline
\end{tabular}

Affairs Canada, 2017).

In the province of Saskatchewan, 205 reserves have been established for 70 First Nations. Not all of the 205 reserves are permanently occupied, but rather some reserves are used for subsistence purposes (e.g., hunting, trapping, and fishing). Other reserves have been set aside for non-renewable resource extraction and some are used for the continuance of cultural activities. The total First Nation population in Saskatchewan is estimated to be 114,570, of which 54,460 (47.5 percent) reside on-reserve. The total First Nation population represents roughly 11 percent of Saskatchewan's total population (Census 2016). The 70 First Nations in Saskatchewan are culturally and politically diverse. This diversity is reflected in five distinct linguistic groups. They are signatory to six historic treaties (Treaties 2, 4, 5, 6, 8, and 10).

Among the 70, First Nations in Saskatchewan are the One Arrow First Nation (OAFN) and the Beardy's Okamasis First Nation (BOFN). The OAFN entered into Treaty 6 in 1878. The OAFN reserve was established approximately $100 \mathrm{~km}$ north of Saskatoon (see Figure 1 ). Since that time, and on the basis of revised population estimates, 13 additional reserves have been established, totalling 3,776 hectares. As of 2019, the total population of OAFN is 1,986 , of which 761 members live on-reserve. The services found on the OAFN reserves are minimal but include a general store, rodeo grounds, sports grounds, school, health clinic, band office, skating rink, fire hall, band hall, and community maintenance facilities (water treatment plant and pumping station). However, one of OAFN's reserves (Sounding Sky Reserve) is located within the city of Saskatoon where they have established a successful gas and convenience store, as well as a 15-unit apartment complex for OAFN members.

Located directly west of OAFN is the Beardy's Okemasis First Nation (BOFN). The BOFN entered into Treaty 6 on August 28, 1872 and its main reserve was established just west of Duck Lake, Saskatchewan (population 610). In addition to its main reserve, BOFN has seven other reserves, totalling 20,346 hectares. The BOFN population in 2019 was 3,503, with 1,336 members residing on-reserve. On-reserve businesses are few and include a convenience store and gas bar, an accredited Health Clinic, a Federal Minimum Security Healing Lodge, and a water treatment facility. Like the OAFN, as well as other First Nations in the province, BOFN has a very young population, who have limited educational achievement, lower than average incomes, limited employment opportunities, and a reliance on government transfers (see Table 1).

(c)Southern Regional Science Association 2020. 


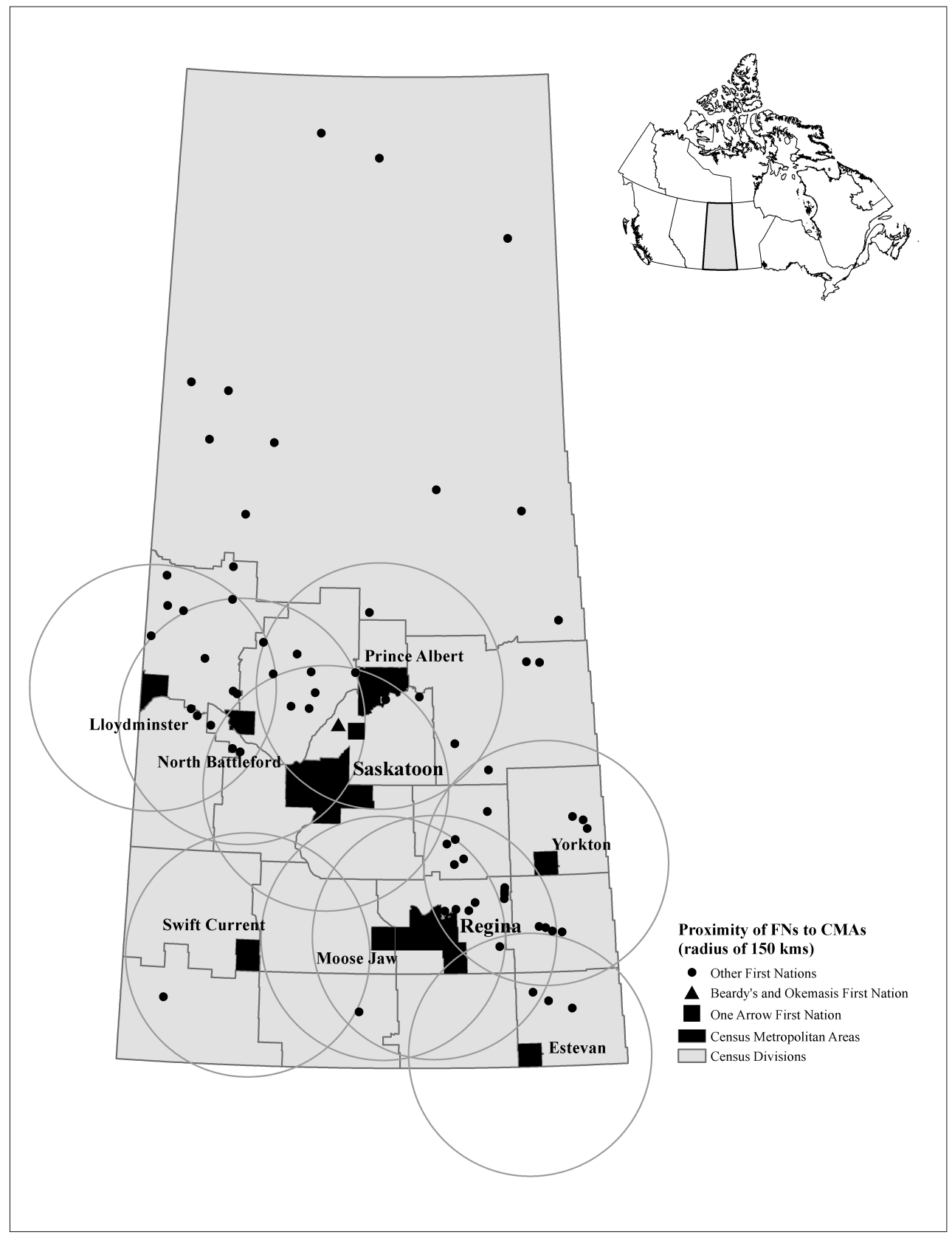

Figure 1: Geographical Distribution of Saskatchewan First Nations and Census Metropolitan Areas (CMAs) 


\subsection{Methodology}

\subsubsection{Leakage Study}

Between April and July 2015, household surveys were administered to 256 on-reserve households, including 156 (92 percent) OAFN households and 100 (32 percent) BOFN households. This sample represents 53 percent of all on-reserve households for these two First Nations. ${ }^{1}$ Teams of First Nation researchers administered the surveys face-to-face to male and/or female heads of household. The surveys included a series of demographic questions, including age, gender, and employment characteristics of household members. Respondents were then asked to estimate their household's total monthly expenditures based on list of expense categories (e.g., food, clothing, appliances, entertainment, others), including purchasing history, location of purchase (town and name of store), total amount spent, and frequency of purchasing. All expenditures were then aggregated to an annual basis and pooled together in terms of expense categories and locations of purchase.

To calculate total spending of First Nations' government departments, annual consolidated audits were examined. These audits identified the total annual revenue generated from businesses, as well as from federal government transfers. Annual audits were used to calculate total annual expenditures for goods and services. These expenditures include both operational and investment spending. Wherever it was possible, amortization costs were removed to represent the actual expenditures made by each First Nation.

To determine the total spending of all 70 First Nations, we use the average between OAFN and BOFNs' median household expenditures as a proxy for all First Nation household spending. ${ }^{2}$ To estimate the total spending of each Nation's government for 68 of the 70 First Nations in the province, we accessed data made available through First Nations Financial Transparency Act (FNFTA). ${ }^{3}$ Under the requirements of this Act, First Nations publicly disclose their annual consolidated audits and the schedules of all service related expenses (Indigenous and Northern Affairs Canada, 2013). These consolidated audits were used to determine the total amount spent by First Nation governments for various goods and services.

\subsubsection{Multiplier Effect}

Based on our estimate of the annual household expenditures for OAFN and BOFN, the total annual household expenditures for the other 68 First Nations were estimated. These estimates are thought to be reasonable for three reasons. First, the total households' expenditures for other First Nations is adjusted for their population. Second, our results show that the majority of households' expenditures were made on transportation, food, and household operations in which, arguably, the most important factors are the distance to a population center, especially for transportation, and size of the household. Third, the geographical distribution pattern of Saskatchewan First Nations is relatively homogenous with respect to

\footnotetext{
${ }^{1}$ Percentages are based on Census 2016 data.

${ }^{2}$ Our results indicate that only 2.5 percent of household spending was made out of the province. This proportion has not been assumed to be necessarily true in other First Nations. All expenditures have been assumed to be within the province.

${ }^{3}$ Data were available for only 68 of the 70 First Nations in Saskatchewan.
}

(C)Southern Regional Science Association 2020. 
distances to the population centers. The majority of Saskatchewan First Nations (56 or 80 percent) are located within $150 \mathrm{~km}$ of at least one of the nine Census Metropolitan Areas (CMAs). These CMAs include Saskatoon, Regina, Prince Albert, Moose Jaw, North Battleford, Yorkton, Swift Current, Estevan, and Lloydminister (see Figure 1). For these reasons, we assumed relative homogeneity between First Nations in terms of household spending.

Considering the aggregate spending for all 70 First Nations, the multiplier effects of all final demand from First Nations' spending were calculated based on Input-Output tables developed by Statistics Canada. Canadian I-O tables are derived from surveys, tax records, and other administrative sources. The economic activities documented are those by consumers (both domestic consumption and imported goods and services), producers (both production for domestic markets and export markets), governments, and non-profit organizations. Originally, the Canadian I-O system has been rectangular where inputs and outputs of industries are classified by commodity. The I-O multipliers are then developed based on a square matrix i.e. the industry-by-industry matrix. Due to confidentiality reasons, I-O tables at the provincial/territorial level are available only at a higher level of aggregation of industries than at the national level. Statistics Canada provides four different types of multipliers, specifically output, Gross Domestic Product (GDP), income, and employment.

Output multipliers translate actual expenditures into total output or production requirements as a result of an increase in final demand expenditures, including the inputs required to produce the output represented by the new demand. GDP multipliers represent the change in local value added associated with a unit change in final demand (Ghanem, 2005). Only that portion of the value of new production that becomes a factor of payments (wages, rents, profits, and interest) is represented, so this multiplier will always be less than one. Income multipliers estimate the changes in wages and salaries due to an increase in final demand, that is, the portion that becomes income to someone in Saskatchewan (Ghanem, 2005). Employment multipliers represent the change in employment (Ghanem, 2005), and in this paper, the number of jobs created per million dollars spent by First Nations. Three of these four multipliers (GDP, income, and employment) were used to assess the provincial impact of First Nations' spending.

An illustration of principal computational foundations of I-O models and multipliers is presented here as a background of the research methodology used in this study. Considering an economy with $n$ sectors, the total final demand for each sector can be written as:

$$
X_{i}=z_{i 1}+z_{i 2}+\cdots+z_{i n}+Y_{i}
$$

where $i \in[1, n] . z$ represents the interindustry sales by sector $i$ and $Y_{i}$ represents sector $i$ s sales to final demand.

Across entire $n$ sectors in the economy, equation (1) can be written as the following set of equations.

(c)Southern Regional Science Association 2020. 


$$
\begin{aligned}
& X_{1}=a_{11} X_{1}+a_{12} X_{2}+\cdots+a_{1 n} X_{n}+Y_{1} \\
& X_{2}=a_{21} X_{1}+a_{22} X_{2}+\cdots+a_{2 n} X_{n}+Y_{2} \\
& \vdots \\
& X_{i}=a_{i 1} X_{1}+a_{i 2} X_{2}+\cdots+a_{i n} X_{n}+Y_{i} \\
& \vdots \\
& X_{n}=a_{n 1} X_{1}+a_{n 2} X_{2}+\cdots+a_{n n} X_{n}+Y_{n}
\end{aligned}
$$

which could be written in a matrix form as:

$$
(I-A) X=Y \Rightarrow X=(I-A)^{-1} Y
$$

where matrix $A$ represents technical coefficients between different sectors of the economy, matrix $X$ represents final demands for each sector, and matrix $Y$ represents each section's sales to final demand, as follows

$$
A=\left[\begin{array}{cccc}
a_{11} & a_{12} & \cdots & a_{1 n} \\
a_{21} & a_{22} & \cdots & a_{2 n} \\
\vdots & \vdots & \ddots & \vdots \\
a_{n 1} & a_{n 2} & \cdots & a_{n n}
\end{array}\right]_{n * n} \quad X=\left[\begin{array}{c}
X_{1} \\
X_{2} \\
\vdots \\
X_{n}
\end{array}\right]_{n=1} Y=\left[\begin{array}{c}
Y_{1} \\
Y_{2} \\
\vdots \\
Y_{n}
\end{array}\right]_{n * 1}
$$

The concept of I-O multipliers originates from assumed exogenous changes in final demand of different sectors. For instance, an output multiplier for sector 1, is defined as the total value of production in all sectors of the economy that is necessary to satisfy a dollar's worth of final demand for sector 1's output. Depending on how one defines the total value of production, multipliers will be defined as either simple or total. For instance, the total output multiplier includes the direct, indirect, and induced effects whereas the simple output multiplier only includes direct and indirect effects. An additional dollars worth of final demand for the output of sector 1 , denoted as $(\Delta Y)_{1}$, would be reflected as:

$$
(\Delta Y)_{1}=\left[\begin{array}{c}
1 \\
0 \\
0 \\
\vdots \\
0
\end{array}\right]
$$

Hence, the implication - for all sectors in the economy - of an additional dollar's worth of final demand for sector 1's output, denoted as $(\Delta \mathrm{X})_{1}$, would be calculated from

$$
(\Delta \mathrm{X})_{1}=(I-A)^{-1}(\Delta \mathrm{Y})_{1}
$$

Assuming the availability of matrix of coefficients $A$, one can calculate the matrix $B=$ $(I-A)^{-1}$. The elements of $B$, denoted as $b_{i j},(\Delta \mathrm{X})_{1}$ can be calculated via 


$$
(\Delta \mathrm{X})_{1}=\sum_{i=1}^{n} b_{i 1}
$$

Therefore, in general, the simple output multiplier for sector $j$, denoted as $M_{j}$, is given by

$$
\mathrm{M}_{j}=\sum_{i=1}^{n} b_{i j} .
$$

The simple output multiplier considers the direct and indirect effects, obtained from a model in which households are assumed to be exogenous. The total output multiplier accounts for the direct and indirect effects as well as the induced effects. Through household income generation, induced effects account for labor income in a given economy. The total output multiplier could be calculated by adding another sector to the economy, households. This makes the coefficient matrix i.e. $\bar{A}$ to be of dimension $(n+1 * n+1)$. The total output multiplier for sector $j$, denoted as $\bar{M}_{j}$ is given by:

$$
\overline{\mathrm{M}}_{j}=\sum_{i=1}^{n+1} \bar{b}_{i j}
$$

where $\bar{b}_{i j}$ represents elements of a new matrix $\bar{B}$, derived from $\bar{A}$.

Income multipliers can be derived by taking a step further. A simple household income multiplier, denoted by $I_{j}$, could be derived using:

$$
\mathrm{I}_{j}=\sum_{i=1}^{n} a_{n+1, i} x_{i j}
$$

where $x_{i j}$ represents elements of matrix $(\Delta \mathrm{X})_{j}$, originating from an initial $\$ 1$ change in final demand for sector $j$ using coefficients in Matrix $B$ i.e. calculated from Eq. 5. A total household income multiplier, denoted by $\bar{I}_{j}$, could be derived using

$$
\overline{\mathrm{I}}_{j}=\sum_{i=1}^{n+1} a_{n+1, i} \bar{x}_{i j}
$$

where $x_{i j}$ represents elements of matrix $(\overline{\Delta X})_{j}$, originating from an initial $\$ 1$ change in final demand for sector $j$ using coefficients in Matrix $\bar{B}$. Using the same principles, employment multipliers can be derived. However, in calculation of employment multipliers, instead of monetary labor input coefficients, the physical labor input coefficients are considered (Miller and Blair, 1985).

There are limitations to this approach that we acknowledge. For example, I-O models have been criticized for using fixed coefficients and a lack of supply side constraints (Coughlin and Mandelbaum, 1991; Bess and Ambargis, 2011). In addition, I-O tables are developed based on the assumption that the interrelation between different industries in an economic system remains unchanged during the year. Another assumption, the lack of a supply side, 
implies that industries can respond to increases in demand by recruiting more inputs, and therefore increase production to meet the increase in demand. However, there is a limit on most inputs, especially at the regional level. While these assumptions might be challenging in some cases, I-O models and multiplier effect analyses originating from them are arguably the most transparent approaches for conducting different types of economic impact studies that are used to assess sectoral contributions and priorities in an economy (Mattas and Shrestha, 1991; Toh and Thangavelu, 2012), economic benefit analyses (Carr et al., 2013), and economic cost analyses (Okuyama and Santos, 2014; Santos et al., 2014; Vasconcelos and Tapia, 2015).

\section{RESULTS}

Using the model depicted above, we estimate OAFN and BOFN economic leakage rates to be 90 percent and 91.4 percent, respectively. The percentage of revenue that is spent onreserve is limited largely to fuel $(\$ 535,000)$ and tobacco $(\$ 600,000)$ purchases. In the case of OAFN and BOFN (as with all other Saskatchewan First Nations), on-reserve stores enroll in the Provincial Fuel and Tobacco Tax Refund Program that removes Provincial Sales Tax (6 percent) on fuel and tobacco products for First Nation members. The tax deductions are a significant incentive for on-reserve spending for these goods. However, on-reserve spending for other goods and services is limited due to high costs and limited product inventories.

Table 2 summarizes the economic leakage for OAFN and BOFN. Our results indicate that First Nation households spend over $\$ 12$ million on goods and services annually, of which, approximately $\$ 11$ million is spent off-reserve. Food expenditures, estimated at over $\$ 4$ million (33 percent of spending), is the largest household expenditure, followed by transportation costs at over $\$ 3.3$ million. Combined, Food and Transportation costs account for over 60 percent of total household spending. Geographically, $\$ 9.3$ out of $\$ 12$ million in household spending occurs in Saskatoon and Prince Albert, the two closest CMAs to OAFN and BOFN. This accounts for approximately 77 percent of the total household spending. The other 23 percent supports 12 other regional economies.

Table 3 presents the estimated impact of household spending on provincial GDP, the number of jobs created (employment), and labor income. Each index is followed by a percentage of total contribution. We estimate that annually, OAFN and BOFN's household spending alone contributes approximately $\$ 10$ million to Saskatchewan's GDP, helps to create approximately 125 jobs, and leads to an estimated increase of $\$ 5.4$ million in labor income for the province. When aggregated for all 70 First Nations,${ }^{4}$ it is estimated that on-reserve First Nation households' spending contributes over $\$ 245$ million (0.39 percent) to Saskatchewan's GDP, helps to create approximately 3,232 jobs (0.73 percent), and leads to an estimated increase of over $\$ 139$ million (0.56 percent) in labor force income for the province.

When spending from First Nation governments is included the impacts are even more pronounced, with $\$ 741$ million (1.17 percent) added to Saskatchewan's GDP, the creation of 11,244 jobs (2.55 percent) and an estimated increase of over $\$ 462$ million (1.86 percent) in labor force income for the province (see Table 4).

\footnotetext{
${ }^{4}$ All estimates are deflated to 2010 using 2015 Saskatchewan's CPI (Statistics Canada 2016).
} 
Table 2: OAFN and BOFN Economic Leakage Results

\begin{tabular}{lclc}
\hline \hline Where did you spend your money? & & How did you spend your money? & \\
\hline Location & Annual $\$$ & Category & Annual \$ \\
OAFN Reserve & 514,752 & Food & $3,969,224$ \\
BOFN Reserve & 633,038 & Transportation & $3,362,738$ \\
Saskatoon & $5,096,887$ & Clothing & $1,117,772$ \\
Prince Albert & $4,590,519$ & Household operations & $1,655,808$ \\
Duck Lake & 535,272 & Recreation & 806,213 \\
Rosthern & 412,528 & Tobacco products & 598,466 \\
Out of province (Manitoba \& Ottawa) & 307,897 & Household furnishing and equipment & 280,624 \\
Humboldt & 19,836 & Professional services & 219,432 \\
Wakaw & 27,492 & Personal care & 50,122 \\
Hague & 1,308 & Education & 64,804 \\
Cudworth & 1,800 & Others & 27,070 \\
Regina & 10,704 & & \\
Warman & 240 & & $12,152,273$ \\
Total & $12,152,273$ & Total \\
\hline \hline
\end{tabular}

\section{DISCUSSION}

Household consumption constitutes a significant portion of the GDP in any economy. In Saskatchewan, household final consumption is estimated to constitute approximately 36 percent of the nominal GDP in 2014 (Saskatchewan Bureau of Statistics, 2018). However, First Nation communities and reserve economies are, in most cases, deprived from this contribution due to high economic leakage rates. A comparison of previous leakage studies between First Nation and other communities indicates that estimated economic leakage rates are significantly higher in First Nation communities. In a regional leakage study done in Lillooet, British Columbia, 60-75 percent of residents reported they make out-of-the-region purchases for categories such as clothing, furniture, and electronics. Approximately 8 percent had made out-of-the-region purchases for services such as home maintenance and repairs (Fraser Basin Council 2014). In another leakage study conducted in the West Nipissing municipality in Ontario, the estimated leakage rate in retail sector was estimated to be approximately 25 percent (Cachon and Lagrandeur, 2015).

Our results indicate that economic leakage rates are 90 percent and 91.4 percent, for OAFN and BOFN, respectively. This means that 90 cents of every dollar earned by onreserve households, immediately leaves the community and is spent on goods and services found off-reserve. The impacts associated with this high level of leakage, and the absence of local spending, result in stagnant economic growth, few wealth generating opportunities, and the perpetuation of lower standards of living for First Nation members. The primary cause of economic leakage on First Nation reserves can be attributed to the lack of on-reserve business that can provide valued goods and services (Aboriginal Investment Services, 2010; Unama'ki Economic Benefits Office, 2011; Miller, 2012; Meyers Norris Penny, 2014; Clarkson and Murphy, 2016).

Various strategies have been proposed to reduce economic leakage and strengthen the on-reserve economies of First Nations in Canada and Native American tribes in the United 
Table 3: Economic Impact of OAFN and BOFN on Saskatchewan's Economy Household Expenditure Level

\begin{tabular}{|c|c|c|c|c|c|}
\hline & & \multicolumn{2}{|l|}{ OAFN } & \multicolumn{2}{|l|}{ BOFN } \\
\hline & & $\begin{array}{l}\text { Total } \\
\text { contribution } \$\end{array}$ & $\begin{array}{l}\text { Total } \\
\text { contribution \% }\end{array}$ & $\begin{array}{l}\text { Total } \\
\text { contribution } \$\end{array}$ & $\begin{array}{l}\text { Total } \\
\text { contribution \% }\end{array}$ \\
\hline \multirow{9}{*}{ GDP } & Transportation and warehousing & 940,451 & 0.0015 & $1,628,222$ & 0.0026 \\
\hline & Accommodation and food services & $1,240,964$ & 0.0020 & $1,708,977$ & 0.0027 \\
\hline & Retail trade & 942,295 & 0.0015 & 902,562 & 0.0014 \\
\hline & Arts, entertainment and recreation & 285,407 & 0.0005 & 337,114 & 0.0005 \\
\hline & Professional, scientific and technical services & 103,902 & 0.0002 & 92,741 & 0.0001 \\
\hline & Utilities & 321,434 & 0.0005 & 945,280 & 0.0015 \\
\hline & Other services (except public administration) & 5,006 & 0.0000 & 38,190 & 0.0001 \\
\hline & Educational services & 1,747 & 0.0000 & 51,269 & 0.0001 \\
\hline & Total & $3,841,206$ & 0.0061 & $5,779,398$ & 0.0091 \\
\hline \multirow{9}{*}{ Employment } & Transportation and warehousing & 9 & 0.0054 & 15 & 0.0075 \\
\hline & Accommodation and food services & 24 & 0.0054 & 33 & 0.0075 \\
\hline & Retail trade & 14 & 0.0032 & 13 & 0.0029 \\
\hline & Arts, entertainment and recreation & 4 & 0.0009 & 5 & 0.0011 \\
\hline & Professional, scientific and technical services & 1 & 0.0002 & 1 & 0.0002 \\
\hline & Utilities & 1 & 0.0002 & 3 & 0.0007 \\
\hline & Other services (except public administration) & 0 & 0.0000 & 1 & 0.0002 \\
\hline & Educational services & 0 & 0.0000 & 1 & 0.0002 \\
\hline & Total & 53 & 0.0119 & 72 & 0.0162 \\
\hline \multirow{9}{*}{ Labor Income } & Transportation and warehousing & 500,451 & 0.0020 & 866,442 & 0.0035 \\
\hline & Accommodation and food services & 805,895 & 0.0033 & $1,109,827$ & 0.0045 \\
\hline & Retail trade & 586,109 & 0.0024 & 561,394 & 0.0023 \\
\hline & Arts, entertainment and recreation & 174,697 & 0.0007 & 206,347 & 0.0008 \\
\hline & Professional, scientific and technical services & 65,233 & 0.0003 & 58,225 & 0.0002 \\
\hline & Utilities & 100,025 & 0.0004 & 294,157 & 0.0012 \\
\hline & Other services (except public administration) & 3,307 & 0.0000 & 25,229 & 0.00 \\
\hline & Educational services & 1,319 & 0.0000 & 38,698 & 0.0001 \\
\hline & Total & $2,237,036$ & 0.0091 & $3,196,449$ & 0.0129 \\
\hline
\end{tabular}

Table 4: Economic Impact of First Nation Spending

\begin{tabular}{|c|c|c|c|c|}
\hline & $\begin{array}{c}\text { Estimated } \\
\text { Spending } \\
\text { (deflated to 2010) }\end{array}$ & $\begin{array}{c}\text { Contribution } \\
\text { to } \\
\text { GDP }\end{array}$ & $\begin{array}{c}\text { Contribution } \\
\text { to Job } \\
\text { Creation }\end{array}$ & $\begin{array}{l}\text { Contribution to } \\
\text { Labor } \\
\text { Force Income }\end{array}$ \\
\hline First Nation Household Spending & $\$ 284$ million & $\begin{array}{c}\$ 245 \text { million } \\
(0.39 \%)\end{array}$ & $\begin{array}{c}3,232 \\
(0.73 \%)\end{array}$ & $\begin{array}{c}\$ 139 \text { million } \\
(0.56 \%)\end{array}$ \\
\hline First Nation Government Spending & $\$ 527$ million & $\begin{array}{c}\text { \$496 million } \\
(0.78 \%)\end{array}$ & $\begin{array}{c}8,012 \\
(1.82 \%)\end{array}$ & $\begin{array}{c}\$ 323 \text { million } \\
(1.30 \%)\end{array}$ \\
\hline Total Spending & $\$ 811$ million & $\begin{array}{c}\$ 741 \text { million } \\
(1.17 \%)\end{array}$ & $\begin{array}{c}11,244 \\
(2.55 \%)\end{array}$ & $\begin{array}{c}\$ 462 \text { million } \\
(1.86 \%)\end{array}$ \\
\hline
\end{tabular}

States. Table 5 summarizes the most relevant causes of high economic leakage along with suggested strategies to reduce leakage in reserve economies. These studies suggest that if a greater proportion of First Nation spending could be recaptured, the multiplier effects could be significant for First Nation economic development (Aboriginal Investment Services, 2010; Unama'ki Economic Benefits Office, 2011; Miller, 2012; Meyers Norris Penny, 2014; Clarkson and Murphy, 2016; Regan and Anderson, 2016).

Using our refined multipliers for First Nation communities, this study argues that if characteristics of a relatively large group of regional residents are considered, one can estimate the impacts of households' spending more accurately. When the population of interest is large and distinct enough, the cost of developing refined multipliers might be worth it (Deller et al., 1993). This could create estimates that are more reflective of the population's actual impacts. Furthermore, this study underlines the significance of First Nations' spending at the provincial level. Despite the significance, our results show that First Nation communities are often deprived from multiplier effects of such expenditures due to high economic leakage rates. Estimation of the economic impacts of First Nations spending shows the potential 
significance of economic development opportunities, if lost revenue is recaptured by onreserve economies.

However, recapturing lost revenue through business and entrepreneurial development has proven challenging due to unique barriers faced by First Nations. Miller (2012) suggests that entrepreneurs typically secure start-up capital in one of three ways, including asset-based loans ( i.e. loans backed by home mortgages), regular loans (i.e. non-asset-based loans), and accumulated family wealth. Yet the opportunity for First Nation entrepreneurs to access asset-based and non-asset-based loans is limited for a number of reasons. Foremost are the constraints found in Canada's far-reaching Indian Act (1876), which has for nearly 150 years defined the relationship between Federal and First Nation Governments. In most treaty areas of Canada, First Nation citizens do not own their homes or property, but rather reserve lands "are held by Her Majesty for the use and benefit of the respective bands ... [where] the Governor in Council may determine whether any purpose for which lands in a reserve are used or are to be used" (Canadian Indian Act, 1876, Section 19(1)). Lacking title to homes and property, First Nation citizens often lack the necessary collateral to secure loans to start or expand private on-reserve businesses (Mitchell and Morse, 2003; Alcantara, 2007). For those First Nations who do manage to secure the necessary financing, the additional transaction costs associated with Federal approvals and administrative oversight can be four to six times greater than establishing the same business off-reserve (Richard et al., 2008). These conditions have contributed to fewer businesses being established on-reserve, which in turn, has led to a lack of employment opportunities, fewer business mentors, shortages of skilled employees, and inadequate business infrastructure.

Since the majority of on-reserve residents do not hold title to homes or property, financial institutions are reluctant to provide start-up capital. In addition, a long history of poverty and inconsistent employment and credit histories among would-be First Nation entrepreneurs puts them in a high-risk category for loan default (Miller, 2012; Regan and Anderson, 2016). For these reasons, business development, and by association personal wealth creation, remains limited on most First Nation reserves.

The motivation for this research rests largely in the recognition by OAFN and BOFN that the first step towards their own economic development was to gain an understanding of the amount and types of economic leakage occurring in their communities. This was considered a foundational piece of information for future business development. With areas of leakage identified, they would be in a better position to secure necessary financing, launch new businesses, and recapture local spending. This in turn would lead to job creation and opportunities for revenue circulation within reserve economies. With this information, new markets could be identified and assessed in terms of business potential. For example, in this study we found that OAFN and BOFN households spend over $\$ 4$ million annually on groceries, take-out food/coffee, and restaurants in neighboring off-reserve areas.

(C)Southern Regional Science Association 2020. 


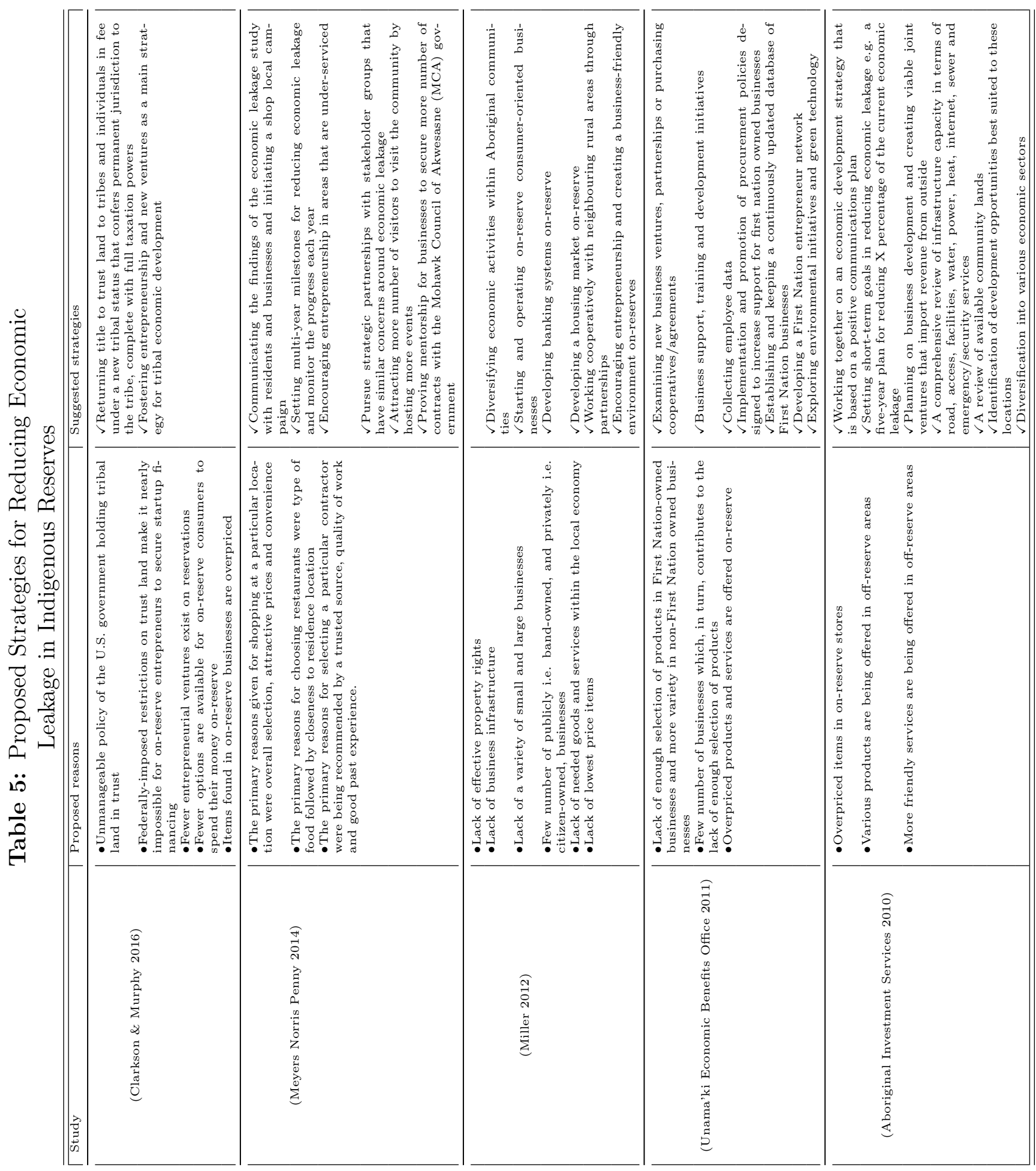

(c)Southern Regional Science Association 2020. 
Although each First Nation owns and operates a convenience store on its own reserve, there is still a high rate of economic leakage for grocery purchases. Our results show that limited inventory and higher prices compared to neighboring off-reserve retailers contributed to this leakage. One strategy now being explored is to pool their collective resources by partnering between themselves or with an established grocer in order to capitalize on economies of scale, thereby enabling them to offer lower prices and a more diversified inventory. This strategy is consistent with other studies that encourage strategic partnerships (Aboriginal Investment Services, 2010; Unama'ki Economic Benefits Office, 2011; Miller, 2012; Meyers Norris Penny, 2014) that facilitate procurement policies designed to improve the financial advantage of First Nation businesses (Unama'ki Economic Benefits Office, 2011). This could also provide opportunities for First Nation entrepreneurs to develop, market, and sell local products and services through established outlets, resulting potentially in business spin-offs and other forms of local investment.

On-reserve business development is a key contributor to sustainable First Nation economic development and it should be a core part of strategic planning and policy making efforts. While this is a reasonable strategy for most First Nation communities, its long-term objective should not be overshadowed by short-term benefits. The goal of developing onreserve businesses should be to increase value added on-reserves. However, if this comes with higher costs and lower quality and variety of consumer goods and services, then residents on-reserves may not be better off, even with more employment.

In Canada, First Nations are beginning to work more closely with the Federal Government to develop strategic plans to establish business-friendly environments. Such environments help to use more of a fast-growing population's labor force in economic activities, reducing costs to the Canadian economy. Until such environments are more established, social welfare programs and government funding will remain necessary. However, all seem to agree that this is not a sustainable solution to the challenges faced by First Nations. While these challenges are complex, and no single strategy will remedy the social and economic conditions plaguing many First Nation communities in Canada, a thorough understanding of economic leakage of First Nation economies, and the recapturing of First Nation spending, represents a necessary step moving forward.

\section{REFERENCES}

Aboriginal Investment Services. (2010) Six Nations and New Credit Economic Leakage Study.

Alcantara, Christopher. (2007) "Reduce Transaction Costs? Yes. Strengthen Property Rights? Maybe: The First Nations Land Management Act and Economic Development on Canadian Indian Reserves," Public Choice, 132(3-4), 421-432.

Assembly of First Nations. (2016) AFN National Chief Says that Federal Budget is a Significant Step in Closing the Gap for First Nations. Last Accessed February 2020 at: https: //www.afn.ca/16-3-22-afn-national-chief-says-federal-budget-a-significant-step-in-c/.

Bess, Rebecca and Zoë O. Ambargis. (2011) "Input-output Models for Impact Analysis: Suggestions for Practitioners using RIMS II Multipliers," In $50^{\text {th }}$ Southern Regional Science Association Conference.

(C)Southern Regional Science Association 2020. 
Cachon, Jean-Charles and Luc Lagrandeur. (2015) "West Nipissing Leakage Analysis and Market Feasibility Study," Chamber of Commerce. Ontario, Canada.

Canadian Centre for Policy Alternatives. (2013) Delivering the Good: Alternative Federal Budget 2015. Last Accessed January 2020 at: https://www.policyalternatives.ca/ publications/reports/alternative-federal-budget-2015.

Carr, Katrina, David C. Natcher, and Rose Olfert. (2013) "Measuring the Economic Impact of Publicly Funded Research in Northern Canada," Polar Geography, 36(4), 291-304.

Clarkson, Gavin and Alisha Murphy. (2016) "Tribal Leakage: How the Curse of Trust Land Impedes Tribal Economic Self-Sustainability," Journal of Law, Economics and Policy, 12, $177-192$.

Coughlin, Cletus C. and Thomas B. Mandelbaum. (1991) "A Consumer's Guide to Regional Economic Multipliers," Federal Reserve Bank of St. Louis Review, 73(January/February 1991).

Daschuk, James William. (2013) Clearing the Plains: Disease, Politics of Starvation, and the Loss of Aboriginal Life, volume 65. University of Regina Press.

Deller, Steven C., N.R. Sumathi, and David W Marcouiller. (1993) "Regional Economic Models for the State of Wisconsin: An Application of the Micro-IMPLAN Modeling System," Working Paper.

Ghanem, Z. (2005) "The Canadian and Inter-provincial Input-output Models: The Mathematical Framework," Industry Canada, Ottawa.

Indigenous and Northern Affairs Canada. (2013) First Nations Financial Transparency Act (FNFTA). Last Accessed February 2020 at: https://www.sac-isc.gc.ca/eng/ 1322056355024/1565374106591. Ottawa, Minister of Justice.

Indigenous and Northern Affairs Canada. (2017) Land Base Statistics. Last Accessed February 2020 at: https://www.aadnc-aandc.gc.ca/eng/1359993855530/1359993914323.

Mattas, Konstadinos A. and Chandra M. Shrestha. (1991) "A New Approach to Determining Sectoral Priorities in an Economy: Input-output Elasticities," Applied Economics, 23(1), $247-254$.

McDonald, Jake. (2017) How a B.C. Native Band went from Poverty to Prosperity. Last Accessed February 2020 at: https://www.theglobeandmail.com/ report-on-business/rob-magazine/clarence-louie-feature/article18913980/?utm_source= Shared+Article+Sent+to+User\&utm_medium $=$ E-mail:+Newsletters $+/+$ E-Blasts $+/+$ etc.\&utm_campaign $=$ Shared + Web + Article + Links.

Meyers Norris Penny. (2014) Mohawk Council of Akwesasne Economic Leakage Study. Last Accessed February 2020 at: http://www.akwesasne.ca/tehotiienawakon/ economic-development/.

Miller, Ronald E. and Peter D. Blair. (1985) Input-Output Analysis. Foundations and Extensions. Prentice-Hall Inc.

Miller, Robert J. (2012) Reservation "Capitalism:" Economic Development in Indian Country. Praeger.

Mitchell, Ronald K. and Eric A. Morse. (2003) "Developing Market Economies: The Aboriginal Case in Northwest British Columbia," In hrisman, James J., Adam D. Holbrook, and Jess H. Chua (Eds.) Innovation and Entrepreneurship in Western Canada: From Family Businesses to Multinationals. University of Calgary Press.

Natcher, David C, Clifford G Hickey, Mark Nelson, and Susan Davis. (2009) "Implications

(C)Southern Regional Science Association 2020. 
of Tenure Insecurity for Aboriginal Land Use in Canada," Human Organization, 68(3), 245-257.

National Collaborating Centre for Aboriginal Health. (2013) An Overview of Aboriginal Health in Canada. Prince George, University of Northern British Columbia. Last Accessed February 2020 at: https://issuu.com/nccah-ccnsa/docs/fs-overviewabororiginalhealth-en. Okuyama, Yasuhide and Joost R. Santos. (2014) "Disaster Impact and Input-output Analysis," Economic Systems Research, 26(1), 1-12.

O’Sullivan, Erin and Mindy McHardy. (2008) "The Community Well-being Index (CWB): Well-being in First Nations Communities, Present, Past, and Future," In White, Jerry P., Dan Beavon, and Nicholas Spence (Eds.) Aboriginal Well-Being: Canada's Continuing Challenge. Thompson Educational Publishing, Inc.

Peredo, Ana Maria, Robert B. Anderson, Craig Galbraith, Benson Honig, and Léo-Paul Dana. (2004) "Towards a Theory of Indigenous Entrepreneurship," International Journal of Entrepreneurship and Small Business, 1(1/2).

Regan, Shawn and Terry L Anderson. (2016) "Unlocking the Energy Wealth of Indian Nations," Unlocking the Wealth of Indian Nations, 107.

Richard, Greg, Jason Calla, and Andre Le Dressay. (2008) "The High Costs of Doing Business on First Nation Lands in Canada". Fiscal Realities Economists.

Santos, Joost R., Krista Danielle S. Yu, Sheree Ann T. Pagsuyoin, and Raymond R. Tan. (2014) "Time-varying Disaster Recovery Model for Interdependent Economic Systems Using Hybrid Input-Output and Event Tree Analysis," Economic Systems Research, 26, 60-80.

Saskatchewan Bureau of Statistics. (2018) Saskatchewan Provincial Economic Accounts. Last Accessed February 2020 at: https://publications.saskatchewan.ca/\#/products/86383.

Smith, Dean Howard. (2000) Modern Tribal Development: Paths to Self-Sufficiency and Cultural Integrity in Indian Country. AltaMira Press.

Stevens, Ernest. (2001) Testimony Before the U.S. Senate Committee on Indian Affairs. Oversight Hearing of the National Gaming Commission. Last Accessed February 2020 at: https: //www.govinfo.gov/content/pkg/CHRG-107shrg74522/html/CHRG-107shrg74522.htm.

Toh, Mun Heng and Shandre Mugan Thangavelu. (2012) "An Input-Output Study of the Singapore Information Sector," Economics Systems Research, 25(2), 233-244.

Unama'ki Economic Benefits Office. (2011) Unama'ki Leakage Study Phase 2, Final Report. Membertou, NS: Unamaki Economic Benefits Office.

Vasconcelos, Paulo Sérgio and Carpiom Lucio Guido Tapia. (2015) "Estimating the Economic Costs of Electricity Deficit Using Input-Output Analysis: The Case of Brazil," 47(9), 916927. Applied Economics.

(c)Southern Regional Science Association 2020. 